\title{
Investigation of use small wind turbines under local wind conditions in Rabka-Zdrój
}

\author{
Aleksandra Szulc-Wrońska ${ }^{1, *}$, Barbara Tomaszewska ${ }^{1}$ \\ ${ }^{1}$ AGH University of Science and Technology, Faculty of Geology, Geophysics and Environmental \\ Protection, Al. Mickiewicza 30, 30-059 Kraków, Poland
}

\begin{abstract}
The paper presents an analysis of wind conditions for the health resort of Rabka-Zdrój. Rabka-Zdrój is a town located in southern Poland in the Rabczańska Valley surrounded by numerous hills. Archival meteorological data were obtained from the Institute of Meteorology and Water Management - National Research Institute, which until 2012 had a retention station in Rabka-Zdrój. A detailed analysis of the basic wind parameters has shown that prevailing wind speeds are in the range of 0.6$1.8 \mathrm{~m} / \mathrm{s}$. In addition, the dominant wind direction is west and southwest. For these directions, the average wind speeds in the analysed period are the highest, with the maximum recorded speed of $2.8 \mathrm{~m} / \mathrm{s}$ for the south-west direction. What is more, in the health resort area, one can observe the frequent occurrence of atmospheric silence, from $16 \%$ to $45 \%$ in the analysed years. The total energy that can be obtained using a small wind turbine is low, therefore the possibility of using hybrid renewable energy sources should be considered.
\end{abstract}

\section{Introduction}

After 2009 the European Union's (EU) climate and energy policy has been directed to measures aimed at reducing energy consumption, reducing greenhouse gas emissions and increasing the share of renewable energy sources in total energy consumption in the EU. Poland as an EU member state should achieve a share of renewable energy in final gross energy consumption of $15 \%$ by 2020 - in accordance with the mandatory targets set in Directive 2009/28 /EC [1].

Over the years 2013-2017 in Poland there was an increase in the share of energy from renewable sources in obtaining primary energy in total from $11.9 \%$ to $14.1 \%$. At the same time, according to the Central Statistical Office (CSO), since 2016 a decline in the share of energy from renewable sources in final gross energy consumption from the level of $11.7 \%$ in 2015 to $11.0 \%$ in 2017 has been observed, which results in an increase in Poland's final gross energy consumption. According to the assumptions of the Energy Policy of Poland by 2030, the demand for electricity will continue to grow. Therefore, for the sake of energy security and the possibility of Polish independence from supplies of oil and natural gas is state policy focused on diversification of sources of supply. The above assumption is

\footnotetext{
*Corresponding author: aszulc@agh.edu.pl
} 
perfectly consistent with renewable energy sources, which are not only an independent source of generating energy, but also provide the opportunity for the development of distributed power engineering.

The share of wind energy in obtaining renewable energy sources from 2013 is increasing annually by approximately $2 \%$. In 2017 , the share of wind energy amounted to $14 \%$ of total energy obtained from renewable energy sources, which corresponds to the energy value of $53673 \mathrm{TJ}$ [2]. The development of technology using wind energy and the annual increase in the total installed wind power capacity confirms the legitimacy of using the potential of wind power in Poland. However, wind energy resources vary across Poland. There is a number of locations, especially at the local level, where the application of high power wind turbines is impossible due to legal requirements, terrain, urban planning and too little wind resources. Large wind investments in such a situation become economically unprofitable and inefficient in terms of energy. Therefore, small wind turbines become the opportunity for areas characterised by relatively low wind speeds $(2-5 \mathrm{~m} / \mathrm{s})$, which are the main element of the so-called home wind installations, often called micro-installations. According to amendment to the Act on Renewable Energy Sources from 2018, the term "micro-installation" should be understood as a renewable energy installation with a total installed electric capacity not higher than $50 \mathrm{~kW}$, connected to a power grid with rated voltage lower than $110 \mathrm{kV}$ or of reachable thermal capacity up to $150 \mathrm{~kW}$, in which the total installed capacity does not exceed $50 \mathrm{~kW}$. [3]

In recent years, the dynamic development of RES micro-installations has been observed, as well as the increase in public interest in this technology. The most popular are micro-installations of renewable energy sources using solar radiation energy, the number of which exceeded 55 thousand in 2018, and the total installed capacity reached $344 \mathrm{MW}$. Wind energy was in the third place in terms of the number of microinstallations installed 68 units and in the fourth place in terms of total installed capacity - 0.37 MW [4].

The estimation of wind energy potential is a key aspect when assessing the possibilities of using wind farm investments. Wind as a parameter characterized by high variability in time and space is strictly dependent on anemological conditions, lay of the land and type of building development. Therefore, the basic objective of the study is a detailed description and recognition of local wind energy resources and the assessment of the possibility of using small wind turbines in the indicated location.

\section{Materials and Methods}

The health resort of Rabka-Zdrój is located in the Rabczańska Valley. The town from the north is sheltered by the hills of Kamionka (620 m above sea level) and Zbójecka Góra (644 $\mathrm{m}$ above sea level), from the south Piątkowa Góra (714 $\mathrm{m}$ above sea level), Maciejowa ( $815 \mathrm{~m}$ above sea level) and Szumiaca ( $841 \mathrm{~m}$ above sea level), and from the east by Bania (607 $\mathrm{m}$ above sea level) and Grzebien (679 $\mathrm{m}$ above sea level). A bit further south and southeast of the health resort there is the Gorce mountain range (1310 $\mathrm{m}$ above sea level), while on the northern side - the Lubon Wielki Massif (1023 m above sea level), which is part of the Island Beskids mountain range [5]. The terrain of the town has a significant impact on both the speed and direction of wind.

In order to assess wind energy resources and the variability of wind speed and direction parameters, archival meteorological data from the meteorological station installed in Rabka-Zdrój were used. Data for analysis were obtained from the Institute of Meteorology and Water Management - National Research Institute (IMWM-NRI). For the purposes of this study, long-term data from the period 2000-2012 were used, which cover a complete series of measurement data, except for 2012, where a series of measurement data was available for a period of 7 months (January-July). The meteorological station was located at 
an altitude of $515 \mathrm{~m}$ a.s.l. near the Sanatorium Cegielski. At the same time, selected data for analysis are the last measurement period conducted by IMWM-NRI in Rabka-Zdrój. Due to the expansion of the immediate surroundings, the station was closed in 2012 because it did not meet the conditions of representativeness specified for meteorological stations. Currently, the town of Rabka-Zdrój IMWM-NRI does not have a measuring station, and therefore does not conduct direct measurements and meteorological observations.

The total accumulated number of measurements of wind speed and direction in the analysed time interval was 27 576. The wind speed and direction measurement data were measured at a height of $10 \mathrm{~m}$ above ground level. On the basis of the measured data for each year, the frequency of occurrence of particular wind directions with the consideration of periods of atmospheric silence was determined. In addition, these data were also compiled for the full measurement period 2000-2012, as an average frequency of wind directions for many years. In addition, average wind speeds for individual wind directions in Rabka-Zdrój were also calculated. In the case of wind speed, average monthly wind speeds in particular years were determined, for which the average monthly wind speed in particular months was determined in relation to the 13 -year measurement period. What is more, for each year, the frequency of occurrence of individual wind speeds was calculated, for which also the average frequency of wind velocity in specific ranges was determined.

The next stage of the analysis was to determine the average wind power and wind energy for the determined speed ranges. The total wind energy at $10 \mathrm{~m}$ above sea level, which can be used by small wind turbines, is the sum of wind energy obtained in individual ranges. Determination of total wind energy during the year started from the $2.0-2.4 \mathrm{~m} / \mathrm{s}$ range, due to the fact that $2 \mathrm{~m} / \mathrm{s}$ is the starting speed in most small wind turbines. Three small wind turbines of different powers were selected for detailed analysis. For each of them, the energy efficiency and power of the wind farm was calculated, taking into account the turbine assembly height. The following formulas were used for the analysis discussed above:

$$
N_{n}=0,6125 \cdot V_{i}^{3}\left[\mathrm{~W} / \mathrm{m}^{2}\right]
$$

$\mathrm{N}_{\mathrm{n}}$ - avegare wind power; $\mathrm{V}_{\mathrm{i}}-$ median class interval

$$
E_{n}=N_{n} \cdot \mathrm{t}_{\mathrm{n}} \quad\left[\mathrm{Wh} / \mathrm{m}^{2} / \text { year }\right]
$$

$E_{n}-$ wind energy calculated for the $n$-th speed interval; $t n-$ duration of speed from the $n$-th interval $[\mathrm{h}]$

$$
E_{\text {net }}=E_{h} \cdot \mathrm{A} \cdot \eta_{\text {total }} \quad[\mathrm{Wh}]
$$

$E_{n e t}-$ net energy obtained from a wind turbine; $A$ - rotor surface; $\eta_{\text {total }}-$ efficiency of the entire system

\section{Results and discussion}

In the years 2000-2012, the highest average monthly wind speeds were recorded in 2002 and 2003 . The average annual speed for these years was $1.6 \mathrm{~m} / \mathrm{s}$. Slightly lower average annual wind speed values occurred in 2004, 2005 and 2008 and amounted, respectively, to $1.4 \mathrm{~m} / \mathrm{s}, 1.5 \mathrm{~m} / \mathrm{s}$ and $1.5 \mathrm{~m} / \mathrm{s}$. In other years, average annual speeds vary between 1.0 and $1.3 \mathrm{~m} / \mathrm{s}$. From the distribution of the average monthly wind speeds shown in Fig. 1, it results that the lowest wind speeds occur in August-October and December. In the indicated period, the average monthly wind speed below $1.3 \mathrm{~m} / \mathrm{s}$ occurred at least in 6 years, with the record value of 9 years achieved for September. The weakest wind, in the analysed time interval, was recorded in January $2010(0.5 \mathrm{~m} / \mathrm{s})$, while the highest in February 2002 $(2.2 \mathrm{~m} / \mathrm{s})$. 


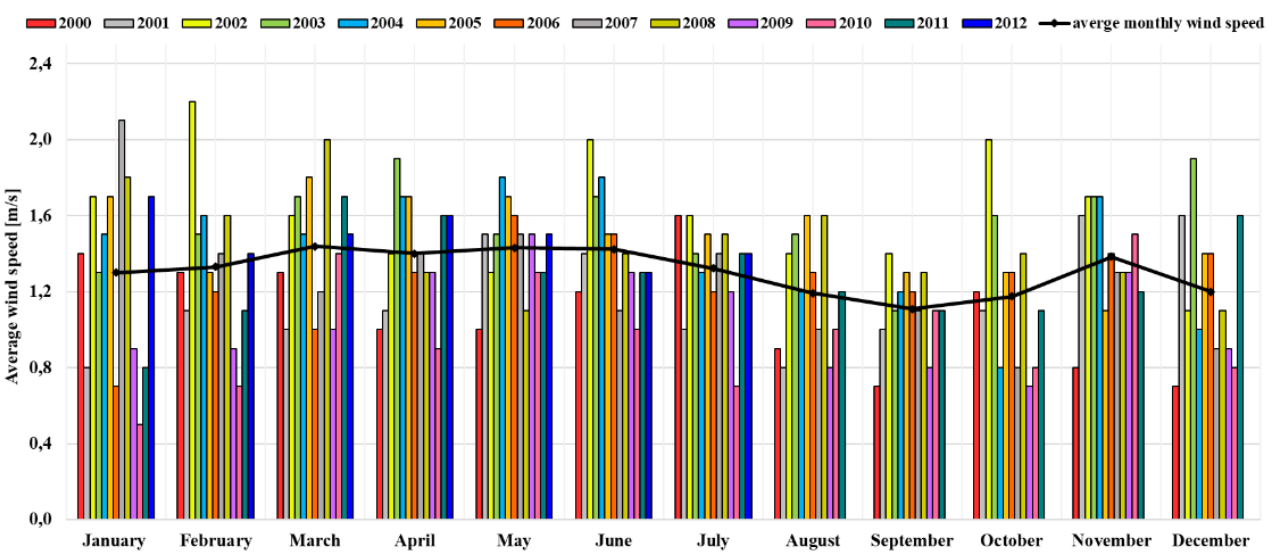

Fig. 1. Distribution of average monthly wind speeds in the years 2000-2012.

The course of the annual frequency of individual wind speeds is shown in Fig.2. The chart shows that in the years 2000-2012 the most frequently occurring wind speeds are in the range $0.6-1.2 \mathrm{~m} / \mathrm{s}(35 \%)$ and $1.2-1.8 \mathrm{~m} / \mathrm{s}(27 \%)$. In order to use wind energy by a small wind turbine, the wind speed must be around $2.0 \mathrm{~m} / \mathrm{s}$. In the case of Rabka-Zdrój, the total frequency of speeds above $2.0 \mathrm{~m} / \mathrm{s}$ is $20 \%$. In the health resort wind speeds above $4.2 \mathrm{~m} / \mathrm{s}$ are very rare, the sum of the frequency ranges of 4.8-6.6 m/s in none of the analysed years exceeded $2 \%$. In the analysed period, only 20 days were recorded with an average daily wind speed above $5.0 \mathrm{~m} / \mathrm{s}$. The highest average daily speed recorded in the years 2000 2012 was $7.3 \mathrm{~m} / \mathrm{s}$.

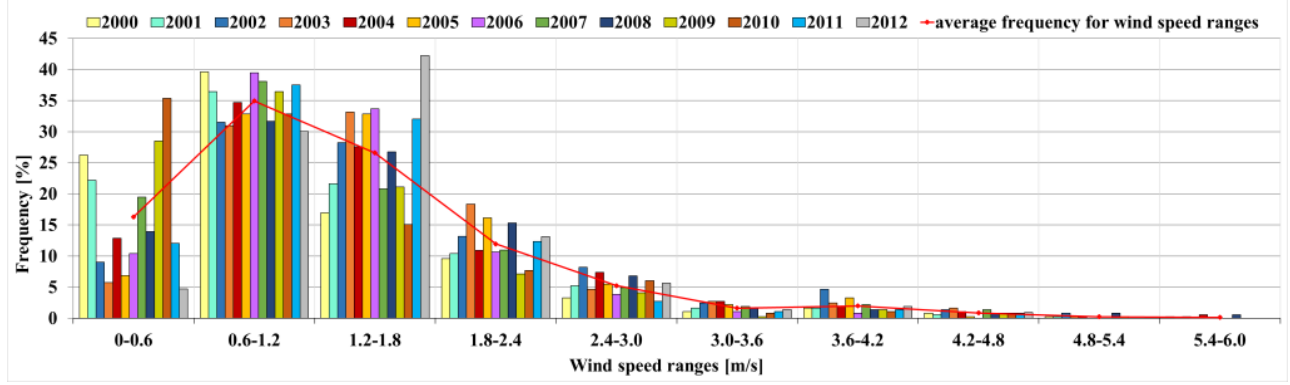

Fig. 2. Distribution of the frequency of average daily wind speeds in the years 2000-2012.

The distribution of wind frequency in built-up areas, i.e. Rabka-Zdrój, is subject to considerable fluctuations due to obstacles in the form of buildings or tall trees. Fig. 3 presents the annual distribution of the frequency of wind directions for selected years from the period 2000-2012. The frequency of annual wind directions varies in individual years, being also accompanied by diversified shares of atmospheric silence throughout the year. For example, in 2006 the distribution of wind directions is relatively evenly distributed between the south and the north-west, with the dominance of southern $(11 \%)$ and western $(10 \%)$ winds. In turn, in 2000 , the dominant directions are south-west by south $(13 \%)$ and south-east by east (10\%). In the years 2002-2012, the dominant wind directions in the area of Rabka-Zdrój were west (8.3\%) and south-west (7.3\%), with an average occurrence of atmospheric silence at $32 \%$. A significant share was also recorded for the south $(7.1 \%)$ and north-west $(6.7 \%)$ directions. While analysing the data, it was noted that in winter the prevailing winds are southern $(9.7 \%)$ and south-western $(8.8 \%)$, while in the case of summer the western winds $(8.8 \%)$ and south-western winds $(7.7 \%)$ dominate. 

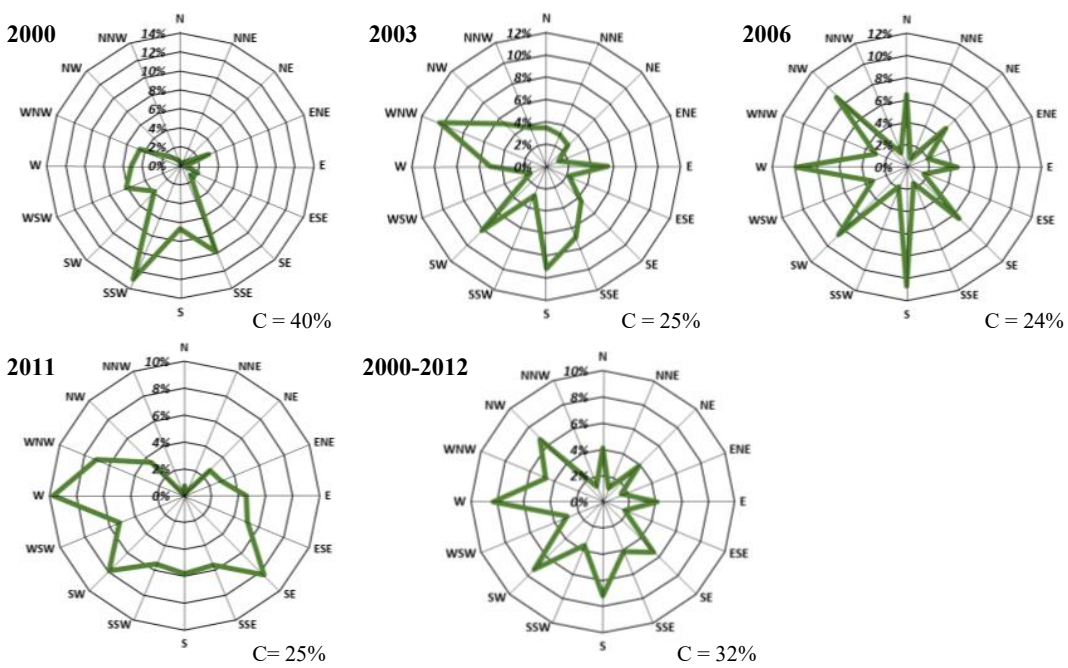

Fig. 3. Wind roses for the annual frequency of wind directions in the years 2002-2012.

In order to determine the most favourable conditions for the use of a small wind turbine, the average wind speeds occurring at individual wind directions were also taken into account (Table 1). On the basis of the calculations, it was found that the most favourable wind directions for which the highest speeds were recorded are found in the southwest-west range. In the majority of the analysed years, these are speeds exceeding $2 \mathrm{~m} / \mathrm{s}$.

Table 1. Average wind speeds obtained at individual wind directions.

\begin{tabular}{|c|c|c|c|c|c|c|c|c|c|c|c|}
\hline $\begin{array}{c}\text { Wind } \\
\text { direction }\end{array}$ & $\mathbf{2 0 0 2}$ & $\mathbf{2 0 0 3}$ & $\mathbf{2 0 0 4}$ & $\mathbf{2 0 0 5}$ & $\mathbf{2 0 0 6}$ & $\mathbf{2 0 0 7}$ & $\mathbf{2 0 0 8}$ & $\mathbf{2 0 0 9}$ & $\mathbf{2 0 1 0}$ & $\mathbf{2 0 1 1}$ & $\mathbf{2 0 1 2}$ \\
\hline N & 2.4 & 2.1 & 1.5 & 1.5 & 1.6 & 1.9 & 1.8 & 2.1 & 1.7 & 1.4 & 1.0 \\
\hline NNE & 1.8 & 1.9 & 1.5 & 1.6 & 1.1 & - & 2.0 & - & - & 1.0 & 1.0 \\
\hline NE & 2.0 & 1.5 & 2.0 & 1.7 & 1.7 & 1.8 & 1.7 & 1.9 & 1.6 & 1.6 & 1.4 \\
\hline ENE & 1.6 & 2.1 & 1.6 & 2.1 & 1.8 & - & 1.4 & - & - & 1.7 & 1.7 \\
\hline E & 1.6 & 1.7 & 1.4 & 1.9 & 1.4 & 1.5 & 1.6 & 1.4 & 1.7 & 1.7 & 1.7 \\
\hline ESE & 2.2 & 1.8 & 1.5 & 1.5 & 1.3 & - & 1.3 & - & - & 1.4 & 1.5 \\
\hline SE & 2.0 & 2.0 & 1.5 & 1.2 & 1.4 & 1.6 & 1.5 & 1.6 & 1.6 & 1.2 & 1.2 \\
\hline SSE & 1.8 & 1.9 & 1.4 & 1.5 & 1.4 & - & 1.5 & - & - & 1.4 & 1.5 \\
\hline S & 3.2 & 2.6 & 1.6 & 1.7 & 1.5 & 1.7 & 1.7 & 1.8 & 2.1 & 1.5 & 1.6 \\
\hline SSW & 2.3 & 2.4 & 2.0 & 1.5 & 2.0 & - & 1.5 & - & - & 1.7 & 1.8 \\
\hline SW & 2.8 & 2.2 & 2.5 & 2.2 & 2.0 & 2.2 & 2.5 & 2.2 & 2.5 & 2.2 & 2.3 \\
\hline WSW & 2.7 & 2.1 & 2.7 & 2.3 & 1.8 & - & 2.6 & - & - & 2.1 & 1.8 \\
\hline W & 2.3 & 2.3 & 2.1 & 2.3 & 1.9 & 2.5 & 2.5 & 2.2 & 2.8 & 2.0 & 1.8 \\
\hline WNW & 2.2 & 2.0 & 2.1 & 1.0 & 1.8 & - & 1.7 & - & - & 2.1 & 2.2 \\
\hline NW & 2.3 & 1.9 & 2.2 & 1.9 & 1.6 & 2.1 & 2.1 & 1.6 & 1.7 & 2.0 & 2.1 \\
\hline NNW & 1.4 & 2.3 & 1.9 & 2.2 & 1.7 & - & 1.3 & - & - & 1.0 & 1.4 \\
\hline
\end{tabular}

The total energy production by selected wind turbines in individual years is presented in Table 2. The analysis has been conducted for two Horizontal Axis Wind Turbines (HAWT) with rated power of $200 \mathrm{~W}$ and $300 \mathrm{~W}$ and two Vertical Axis Wind Turbines (VAWT) with rated power of $300 \mathrm{~W}$ and $500 \mathrm{~W}$. In all the cases the tower height of $12 \mathrm{~m}$ above ground level was assumed. Due to low wind speeds, which dominate in the area of Rabka-Zdrój, turbine energy production is very small. The largest amount of produced energy comes from turbines with the largest rotor surface. The lowest value of energy production was obtained for data from 2009, while the highest for data from 2002 and 2003. The obtained values show that the energy obtained from wind turbines is not able to meet the energy needs of a single-family home. It is estimated that the electricity demand for a house with an area of approx. $150 \mathrm{~m} 2$ equipped with basic electronic devices is around $3700 \mathrm{kWh} /$ year. 
For this reason, the possibility of using small wind turbines in hybrid systems should be considered.

Table 2. Total annual energy production possible to obtain from selected small wind turbines.

\begin{tabular}{|c|c|c|c|c|c|c|c|c|c|c|c|c|c|c|c|c|c|}
\hline & \multirow{2}{*}{ Type } & \multirow{2}{*}{$\begin{array}{c}\text { Rated power } \\
{[\mathrm{W}]}\end{array}$} & \multirow{2}{*}{$\begin{array}{c}\text { Rotor surface } \\
{\left[\mathrm{m}^{2}\right]}\end{array}$} & \multirow{2}{*}{$\begin{array}{c}\text { Start wind speed } \\
{[\mathrm{m} / \mathrm{s}]}\end{array}$} & \multirow{2}{*}{$\begin{array}{c}\text { Rotation } \\
\text { axis }\end{array}$} & \multicolumn{12}{|c|}{ Total annual energy production [kWh] } \\
\hline & & & & & & 2000 & 2001 & 2002 & 2003 & 2004 & 2005 & 2006 & 2007 & 2008 & 2009 & 2010 & 2011 \\
\hline Turbine 1 & VK-0.3/24 g18 & 300 & 0.81 & 1.0 & VAWT & 8,1 & 7,1 & 14,6 & 11,0 & 10,8 & 9,1 & 5,3 & 8,1 & 12,0 & 4,1 & 7,0 & 6,4 \\
\hline Turbine 2 & JFVC-500W & 500 & 2.24 & 2.0 & VAWT & 22,4 & 18,5 & 41,0 & 29,1 & 24,8 & 23,2 & 11,3 & 22,4 & 33,0 & 9,3 & 19,2 & 14,8 \\
\hline Turbine 3 & FD200-2.2 & 200 & 3.80 & 2.0 & HAWT & 38,0 & 31,4 & 69,5 & 49,3 & 42,0 & 39,4 & 19,2 & 38,0 & 55,9 & 15,8 & 32,6 & 25,1 \\
\hline Turbine 4 & FD $500-2.5$ & 500 & 4.90 & 2.0 & HAWT & 49,0 & 40,5 & 89,7 & \begin{tabular}{|c|}
63,7 \\
\end{tabular} & 54,3 & 50,9 & 24,8 & 49,0 & 72,2 & 20,4 & 42,1 & 32,4 \\
\hline
\end{tabular}

\section{Summary}

The article presents an analysis of local wind conditions, which was conducted for the health resort of Rabka-Zdrój in the years 2000-2012. The obtained results indicate that the terrain (location in the valley surrounded by hills) and buildings (urban area with numerous obstacles) have a significant impact on both wind speed and its direction. The annual wind speed is dominated by speeds below $2 \mathrm{~m} / \mathrm{s}$. The distribution of average monthly speeds in individual years has shown that the highest wind speeds occur in the autumn and winter, while the lowest during the summer. The dominant wind directions in the health resort area are west, southwest and south, for which also the highest average wind speeds have been recorded.

A very important element determining the legitimacy of a small wind farm is the amount of wind energy at a certain height, which can be collected and processed by the turbine for electricity or heat. In the case of Rabka-Zdrój, wind energy resources at a height of $12 \mathrm{~m}$, which can be used by small wind turbines, constitute a small percentage per year. The frequency of wind speeds that can be used by small wind turbines does not exceed the level between $20-25 \%$ during the year. In the analysed period of time, significant amounts of atmospheric silence occur in the health resort town, which amount to an average of $32 \%$ per annum. Calculations made for different types of small wind turbines with different rated power show that none of them is able to cover the statistical electricity demand of a singlefamily home. Therefore, in further analyses, the prospect of using small wind turbines in hybrid systems with other types of renewable energy sources will be considered. In addition, two meteorological stations have been installed in the town, in order to be able to show in more detail the spatial variability of wind parameters in the health resort area.

The scientific work was financed from budgetary sources for years 2017-2021, as a research project under the "Diamentowy Grant" programme (grant agreement No DI2016 003946). "The source of data is the Institute of Meteorology and Water Management - National Research Institute".

\section{References}

1. Directive 2009/28/EC of the European Parliament and of the Council of 23 April 2009 on the promotion of the use of energy from renewable sources

2. Central statistical Office, Energy from renewable sources in 2017 (CSO, Warszawa, 2018)

3. Ustawa z dnia 7 czerwca 2018 r. o zmianie ustawy o odnawialnych źródłach energii oraz niektórych innych ustaw (Dz.U. 2018 poz. 1276)

4. Energy Regulatory Office, Report on electricity generated from RES in microinstallation and entered into the distribution network (ERO, Warszawa, 2019)

5. K. P. Turzański, W. Mikuła, M Turzański, Program ochrony środowiska miasta i gminy Rabka-Zdrój (Rabka-Zdrój, 2008) 